\title{
Merkl Márta
}

\section{Food design és digitalizáció ${ }^{1}$}

\author{
Food Design and Digitalisation
}

A vonatkoztatási rendszer, amelybe a vállalás - egy food design elméleti áttekintés és projektbemutatás - be kiván illeszkedni, a negyedik ipari forradalom, illetve az Ipar 4.0. A cikk röviden bemutatja az Ipar 4.0 fogalmát és föbb kérdéseit. Majd válogatott food design projekteket vizsgál egyrészt a különböző direkt (Francesca Zampollo) vagy indirekt (Victoria and Albert Museum) klasszifikációs kísérletek szerint, másrészrôl társadalmi és gazdasági relevanciájú megközelítésekböl (élmény, kritikai jelleg, fenntarthatóság). Az elméleti, spekulatív jellegú kutatás új szempontrendszert kínál a digitális forradalom, az élelmiszeripar és a food design számára.

Kulcsszavak: Ipar 4.0, digitalizáció, élelmiszeripar, élmény, fenntarthatóság, Critical Design, Food Design

The reference system into which the commitment - a food design theoretical overview and project presentations - is intended to fit is the Fourth Industrial Revolution and Industry 4.0. The article briefly introduces the concept and key issues of Industry 4.0. Then it examines selected food design projects according to different direct (Francesca Zampollo) or indirect (Victoria and Albert Museum) classification experiments and approaches with social and economic relevance (experience, critical nature, sustainability). Theoretical, speculative research offers a new set of perspectives for the digital revolution, the food industry, and food design.

Keywords: Industry 4.0, digitalisation, food industry, experience, sustainability, Critical Design, Food Design

Merkl Márta a Budapesti Corvinus Egyetem Gazdálkodástani Doktori Iskola doktori hallgatója. E-mail: marta.merkl@stud.uni-corvinus.hu

Jelen publikáció az Európai Unió, Magyarország és az Európai Szociális Alap társfinanszírozása által biztosított forrásból az EFOP-3.6.3-VEKOP-16-2017-00007 azonosítószámú „Tehetségből fiatal kutató - A kutatói életpályát támogató tevékenységek a felsőoktatásban” című projekt keretében jött létre. 


\section{Bevezetés}

Jelen írás fókuszában a food design, pontosabban digitális food design projektek helyezkednek el. A food design nemzetközi viszonylatokban egyre gyakrabban tárgyalt téma, amely nemcsak a design szcéna, hanem a társadalomtudományok számára is releváns kérdésfeltevésekkel és megoldásokkal szolgálhat. A tárgyalt termékek és szolgáltatások digitális voltából kiindulva alapvető, hogy a negyedik ipari forradalomra és az Ipar 4.0-ra vonatkozó keretet - úgy, mint a fogalomdefiníciót, a hívószavakat, a lehetőségeket és a kihívásokat - áttekintsük, azonban nem ez áll a vizsgálat középpontjában. A food design klasszifikációs kísérleteit, továbbá fontos megközelítéseit - mint az élményorientáció, a fenntarthatóság és a kritikai jelleg - szintén röviden ismertetem. A munka tehát a negyedik ipari forradalomra és az Ipar 4.0-ra, valamint a food designra vonatkozóan elméleti áttekintést, majd projektbemutatást vállal, ezt követve érvényesíti az elméleti hátteret a konkrét projekteknél, és foglalja az elhangzottakat táblázatok segítségével közös keretbe, szintézis jellegú vizsgálatot megvalósítva.

\section{Negyedik ipari forradalom és Ipar 4.0}

A technológiai fejlődés, amely az ipari forradalmak során végbement, visszavezethető az ember életminőségének javítására irányuló igényre, ${ }^{2}$ vagy jellemezhető egyfajta evolúcióként. ${ }^{3} \mathrm{Az}$ ipari forradalmak rövid összefoglalását az 1. táblázat mutatja.

1. táblázat

Ipari forradalmak ${ }^{4}$

\begin{tabular}{|c|c|c|}
\hline Ipari forradalmak & Nagyságrendi idő & Alapja \\
\hline Első & 18-19. század fordulója & gőzgép \\
\hline Második & 19. század vége & $\begin{array}{c}\text { elektromos áram hajtotta berendezések, } \\
\text { belső égésú motorok }\end{array}$ \\
\hline Harmadik & 20. század közepe & számítógépek \\
\hline Negyedik & napjaink & digitalizáció, adat, hálózatok \\
\hline
\end{tabular}

Forrás: Nagy Judit alapján saját szerkesztés

A negyedik ipari forradalom és az Ipar 4.0 fogalmak nem azonosak minden tekintetben: az előbbi jelentéshalmaza szélesebb körû, az utóbbi a vállalati szférára vonatkozik. Az Ipar 4.0 kifejezés a német kormány 2011 és 2020 közötti iparfejlesztési programjából ered. ${ }^{5} \mathrm{Az}$ Ipar 4.0 lehetséges értelmezéseit a 2. táblázat villantja fel.

2 Nagy Judit: Az Ipar 4.0 fogalma és kritikus kérdései - vállalati interjúk alapján. Vezetéstudomány - Budapest Management Review, 50. (2019), 1. 14.

$3 \quad$ Melissa Demartini et alii: Food industry digitalization: from challenges and trends to opportunities and solutions. IFAC PapersOnLine, 51. (2018), 11. 1371.

Nagy (2019) i. m. 14-15.

Nagy (2019) i. m. 15. 
2. táblázat

Ipar 4.0 megközelítései ${ }^{6}$

\begin{tabular}{|c|c|}
\hline Kutató(k) & Meghatározás \\
\hline $\begin{array}{l}\text { Eric Hofmann - Marco Rüsch, } \\
\text { Malte Brettel et alii }\end{array}$ & $\begin{array}{l}\text { termelésre vonatkozó, szúkebb értelmezés, } \\
\text { ipari digitalizáció kifejezés }\end{array}$ \\
\hline $\begin{array}{c}\text { Reinhard Geissbauer - Jesper } \\
\text { Vedso - Stefan Schrauf }\end{array}$ & $\begin{array}{c}\text { digitalizált eszközök és értékteremtési lánc tagjainak } \\
\text { (horizontális és vertikális) integrációja, } \\
\text { digitális ökoszisztéma kifejezés }\end{array}$ \\
\hline Kovács Olivér & $\begin{array}{l}\text { információs és kommunikációs technológiák széles körű } \\
\text { használata }\end{array}$ \\
\hline Klaus Schwab & fizikai, biológiai és digitális technológiák fúziója \\
\hline Gunnar Prause & $\begin{array}{l}\text { új (üzleti) modellek és struktúrák kiépítése, } \\
\text { digitális transzformáció kifejezés }\end{array}$ \\
\hline
\end{tabular}

Forrás: a szerző válogatása és szerkesztése Geissbauer-Vedso-Schrauf, Hofmann-Rüsch, Kovács, Nagy, Prause, valamint Schwab alapján

A digitalizáció az élelmiszeripar összefüggésében alacsony kutatási intenzitással rendelkező terület.7 Szintén információhiány tapasztalható a digitalizáció és a food design közös metszetében elhelyezkedő munkák elemzésében, és jelen írás ennek a hátraléknak a rendezéséhez kíván hozzájárulni.

Az Ipar 4.0 kapcsán beszélhetünk olyan hívószavakról (alkalmazásokról és alkalmazások összességéről), amelyeket a 3. táblázat - teljességre nem törekvő - felsorolása tartalmaz.

$6 \quad$ Reinhard Geissbauer - Jesper Vedso - Stefan Schrauf: Industry 4.0: Building the digital enterprise. Pricewaterhouse-Coopers LLP, 2016. 3-12., 14., 16., 18., 20., 25-26., 28-29., 32.; Erik Hofmann - Marco Rüsch: Industry 4.0 and the current status as well as future prospects on logistics. Computers in Industry, 89. (2017), 24.; Kovács Olivér: Az ipar 4.0 komplexitása. Közgazdasági Szemle, 64. (2017), 7-8. 825.; Nagy (2019) i. m. 15-16.; Gunnar Prause: Sustainable business models and structures for Industry 4.0. Journal of Security and Sustainability Issues, 5. (2015), 2. 159-169.; Klaus Schwab: The Fourth Industrial Revolution: what it means, how to respond. World Economic Forum, 2016.

Demartini et alii (2018) i. m. 1373. 
3. táblázat

Ipar 4.0 technológia- és témavezérelt hivószavai (food design kiegészítésekkel) ${ }^{8}$

\begin{tabular}{|c|c|}
\hline Hívószó & Jelentéstartomány \\
\hline $\begin{array}{c}\text { Internet of Things (a dolgok internete), big (large) data, } \\
\text { data analysis, felhőalapú szolgáltatások }\end{array}$ & $\begin{array}{c}\text { gépek, emberek és gyárak háló- } \\
\text { zatba kapcsolása, adatkezelése }\end{array}$ \\
\hline $\begin{array}{c}\text { kiberfizikai rendszerek (Cyber-Physical System [CPS], } \\
\text { Cyber-Physical Production System [CPPS]), okosgyárak } \\
\text { (okoskonyhák), automatizálás és intelligens robot, ember- } \\
\text { gép interfészek, Human-Machine Interaction (HMI) } \\
\text { (Human-Food Interaction [HFI]) }\end{array}$ & $\begin{array}{c}\text { gépek, emberek és gyárak adat- } \\
\text { és hálóalapú interakciója }\end{array}$ \\
\hline $\begin{array}{c}\text { additív termelés és 3D ételnyomtatás } \\
\text { virtuális és kiterjesztett valóság (Virtual Reality [VR], } \\
\text { Augmented Reality [AR]), hologram }\end{array}$ & $\begin{array}{c}\text { a hagyományos, a feleslegelvételen } \\
\text { alapuló termelési módtól eltéró, } \\
\text { hozzáadáson alapuló termelés }\end{array}$ \\
\hline $\begin{array}{c}\text { information and communication technology (ICT), social } \\
\text { media, Internet of System (IoS), FoodTech }\end{array}$ & $\begin{array}{c}\text { kommuniságon túlmutató digi- } \\
\text { tális valóságok és értékesítési } \\
\text { közegek }\end{array}$ \\
\hline
\end{tabular}

Forrás: DigitalFoodLab: What is FoodTech? é. n., Demartini et alii (2018) i. m., Dolejšová et alii (2018) i. m., Güneş et alii (2018) i. m., valamint Nagy (2019) i. m. alapján a szerző szerkesztése

Kortárs technológiáknak és fúziójuknak jóvoltából képesek lehetünk az élelmiszerrel és étkezéssel összefüggő projekteknél és vállalkozásoknál versenyelőnyt és hatékonyságnövelést elérni, javítani a hulladékgazdálkodáson, továbbá a terméket vagy szolgáltatást személyre szabni (customization) és perszonalizálni (personalization), ugyanakkor kihívás a megfelelően kvalifikált emberi erőforrás, valamint az adat- és élelmiszerbiztonság biztosítása. ${ }^{9}$

A digitális megoldások adta értékteremtés lehetőségével nem él minden szereplő. Ennek okai keresendők a megfelelő stratégia, biztonság, szabványok, munkaerő hiányában, valamint félelmekben a beruházás vagy megtérülés mértékét és az intellektuális vagyon kezelését illetően. ${ }^{10}$

\section{Food design}

A kérdésekre, hogy mi a food design, vagy mi tartozik a food designhoz, nem adhatók egzakt válaszok. A londoni Victoria and Albert Museum (V \& A) - a világ első iparmúvészeti múzeuma, amely designkérdésekben is mértékadó - 2019 őszén kiállítást szentelt

$8 \quad$ DigitalFoodLab: What is FoodTech? é. n.; Markéta Dolejšová et alii: Designing Recipes for Digital Food Futures. In CHI EA, 18: Extended Abstracts of the 2018 CHI Conference on Human Factors in Computing Systems. New York, Association for Computing Machinery, 2018. 1.; Eda Güneş et alii: Gastronomy Four Zero (4.0). International Journal of Environmental Pollution \& Environmental Modelling, 1. (2018), 3. 79.; Nagy (2019) i. m. 16-18.

9 Dolejšová et alii (2018) i. m. 1.; Faludi Julianna: Cukorépítészet, avagy fôzés-e az ételnyomtatás? Café Bábel, 80. (2019), 155.; Güneş et alii (2018) i. m. 78-79.; Nagy (2019) i. m. 19.;

10 Nagy (2019) i. m. 18-23. 
food design projekteknek Food: Bigger than the Plate címmel. A kiállítási szekciók névadásai, azaz a Komposztálás (Compost), Gazdálkodás (Farming), Kereskedelem (Trading) és Étkezés (Eating) indirekt módon nyilatkoznak arról, hogyan látják a kurátorok a terület klasszifikációját. ${ }^{11}$

Francesca Zampollo doktori kutatásának eredményeként létrejött elméleti keret a leggyakrabban idézett a food design definíciója és csoportosítása kapcsán. A food designt tudományterületként azonosítja, és több tudományágra bontja, amit a 4 . táblázat foglal össze. ${ }^{12}$ A zampollói klasszifikáció a terület határait tágabban értelmezi, és nem csupán magának az ételnek vagy italnak a tervezését érti food design alatt, hanem étkezési helyszínek, szituációk, kiegészítő tárgyak, szolgáltatások és nagyobb rendszerek létrehozását is. ${ }^{13}$

4. táblázat

Zampollo-féle food design klasszifikáción ${ }^{14}$

\begin{tabular}{|c|c|}
\hline Szubdiszciplína & Tárgya \\
\hline Food Product Design & élelmiszeripari tömegtermelésre szánt étel \\
\hline Design with Food & itt és most elfogyasztandó étel (nincs szállítás) \\
\hline Design for Food & eszközök az étel elkészítéséhez, tálalásához, tárolásához, szállításához \\
\hline Food Space Design & étel elkészítésére és elfogyasztására szolgáló terek \\
\hline Eating Design & pop-up étkezési helyzetek \\
\hline Food Service Design & szolgáltatás (amit használunk, de nem birtoklunk) \\
\hline Food System Design & étellel, étkezéssel összefüggó tágabb, rendszerszerú környezet \\
\hline
\end{tabular}

Forrás: Zampollo (2016) i. m. alapján a szerző szerkesztése

Az élményorientáció, a kritikai jelleg és a fenntarthatóság olyan attitűdök, amelyek meghatározzák napjaink food design tevékenységét, és amelyek elvezetnek fontos kérdésfeltevésekhez és válaszadásokhoz társadalmi és gazdasági viszonylatokban. ${ }^{15}$

Az étel elsődleges funkciója, a táplálás mellett egyik további funkciója az élményszerzés. Szociológusok és közgazdászok több mint 30 éve foglalkoznak az élmény társadalmi és gazdasági jelentőségének feltérképezésével Gerhard Schultze után az élménytársadalom-elmélet (Erlebnisgesellschaft), valamint Joseph Pine és James H. Gilmore után az élménygazdaság-elmélet (experience economy) keretei között, ami a food design élmény felőli megközelítésének relevanciáját jelzi. ${ }^{16}$

11 Catherine Flood - May R. Sloan: FOOD: Bigger than the Plate. London, Victoria and Albert Museum, 2019.

12 További szubdiszciplína-szerủ attitűdök a rendszerben: Critical Food Design, Sustainable Food Design.

13 Francesca Zampollo: Let's Food Design: 7 Steps to Become a Food Designer. CreateSpace Independent Publishing Platform, 2016.

14 Zampollo (2016) i. m. 13-32., 38-39.

15 A fejezet tartalma bővebben olvasható Merkl Márta: A food design mint társadalmi és gazdasági katalizátor. In Csordás Tamás - Varga Ákos (szerk.): DMMD ADAPTER. Tanulmányok a digitális marketing, média és design területérôl. Budapest, Budapesti Corvinus Egyetem, 2019. 113-118.

16 Gerhard Schulze: Die Erlebnisgesellschaft: Kultursoziologie der Gegenwart. Frankfurt am Main, Campus, 1992.; Joseph B. Pine - James H. Gilmore: The Experience Economy: Work is Theatre \& Every Business a Stage. Boston, Harvard Business Press, 1999.

Európai Tükör 2020/4. 
Fiona Raby és Anthony Dunne - a Critical Design elnevezésű szemlélet képviselői - után a design elsősorban nem arra törekszik, hogy kereskedelmi célokat szolgáljon ki, vagy fizikai szükségleteket elégítsen ki, inkább kritikai perspektívát kíván kirajzolni, amely elgondolkodtat, párbeszédre hív, ezáltal javaslatokat tesz prekoncepciók és jövőszcenáriók megváltoztatására. ${ }^{17}$

Mivel az étkezést nagymértékben meghatározzák kulturális beágyazottságok, a fenntarthatóságnak is kulturális beágyazottsággá kell válnia, amelyhez attitűdformálásra van szükség például az energiagazdálkodás, az ételpazarlás vagy a hulladékgazdálkodás terén. ${ }^{18}$

\section{Példaprojektek}

A következőkben törekedtünk - terjedelmi megkötések figyelembevételével - a széles körű, food design szempontjából kiemelten fontos vagy érdekes (például kulcstervezőkhöz és kulcsiskolákhoz kapcsolódó), külföldi és magyar projektek bemutatására. A válogatás a szakirodalmi áttekintés és egyéni gyűjtés alapján készült.

\subsection{D nyomtatás}

A 3D ételnyomtatás egyre szélesebb területen alkalmazott technológia: ismert egyrészt nagyvállalati hasznosítása (például BlueRhapsody vagy Barilla Lune száraztészták), másrészt kaphatók házi használatra szánt ételnyomtatók (például PancakeBot palacsintanyomtató) vagy 3D nyomtatással készült konyhai eszközök is. Utóbbira példa a magyar fejlesztésű Copy Pasty elnevezésű süteménykiszúró, amelynek formája követi a megrendelő által küldött fotót vagy grafikát. A szerkezet rétegről rétegre építi a csokoládé, cukor, tészta vagy egyéb anyagú, állagát tekintve megfelelő viszkozitású termékeket. ${ }^{19}$ Az ételkísérletek számára izgalmas terepet kínál, ${ }^{20}$ hiszen például a magas proteintartalmú, ám a nyugati kultúrákban elutasított rovarok ételbe foglalását, vagy a nyelési nehézségekben (dysphagiában) szenvedők számára ételfejlesztést tesz lehetővé. ${ }^{21}$

Martí Guixé food designer 2017-ben a Museum für Kunst und Gewerbe Hamburg kiállításán mutatta be Digital Food elnevezésű projektjét, amelynél egy algoritmus 3D nyomtatással készíti el a falatot. Ebben az esetben a szín, a forma, a méret, a textúra és a tápanyag perszonalizált, az íz és az illat nem perszonalizált, hiszen a várakozás

Anthony Dunne - Fiona Raby: Towards a Critical Design. é. n.; Zampollo (2016) i. m. 33-36.

Martin Hablesreiter: Food Design [dokumentumfilm], 2008.

Faludi (2019) i. m. 158.

A piaci esélyeket latolgatva hozzá kell tenni, a nyelési zavarban szenvedő, főleg idős betegek étkezésével foglalkozó egyik projekt, a The Performance Project 2011 és 2015 között futott a Biozoon és a FoodJet vállalati szereplők közreműködésével. A termékfejlesztés során több nehézség merült fel (másodpercek alatt szilárdító anyag, különböző forrásból származó alapanyag heterogén állaga). Végül az eredménytermékben kevés hozzáadott értéke volt a 3D nyomtatás technológiájának. Michael Molich-Hou: Food 3D Printing: What Happened to 3D-Printed Food for the Elderly? 3D Print, 2020.

21 Claudia Banz - Sabine Schulze (szerk.): Food Revolution 5.0. Gestaltung für die Gesellschaft von morgen. Hamburg, Verlag Kettler, 2017. 71-73.; Faludi (2019) i. m. 158.; Güneş et alii (2018) i. m. 80-82. 
szerint a fogyasztóban a megszokott íz biztonságérzetet kelt. Guixé a gondolat bölcsőjét és a mú előfutárát az 1990-es évekre tette, amikor pályakezdő tervezőként megtapasztalta bizonyos ipari és társadalmi körülmények megváltozását, és felismerte, hogy az étel lehet áttervezhető tárgy, amelynek nem feltétlenül kell többé a tradíciót követnie. Az említett körülményeket az ipar hiányában (pontosabban a termelőegységek megszünésében vagy földrajzi áthelyeződésében), valamint a személyi számítógépek és az internet elterjedésében azonosította. ${ }^{22}$

$\mathrm{Az}$ Edible Growth projektet Chloé Rutzerveld jegyzi, aki önmagát mint Future Food Designer definiálja. A projekt 3D nyomtatással hoz létre egy áttört szénhidrátstruktúrát, amelynek belsejében magok, spórák és élesztő keverékén növények és gombák teremnek meg néhány nap alatt a felhasználó otthonában. ${ }^{23}$

\subsection{Urban farming}

A városi kertészkedés vagy földmúvelés megvalósul a fent említett Edible Growth projekt esetében is, hiszen a tárgy megfelel egy miniatűr, ehető ökoszisztémának.

$\mathrm{Az}$ OpenAg ${ }^{\mathrm{TM}}$ Personal Food Computer a Massachusetts Institute of Technology inkubációjában létrejött, nyílt forráskódú platform, amely mesterségesen produkálja adott növényeknek a szükséges természeti kritériumokat. ${ }^{24}$

\subsection{Húshelyettesitő termékek}

Schwab szerint a technológiák fúziója jellemzi az Ipar 4.0-t, amelyben összekapcsolódnak a természettudományok diszciplínái a digitális világgal. ${ }^{25}$ Ezt ki kell egészíteni azzal, hogy az összekapcsolódásban részt vehet a design is. A szövetsebészet (tissue engineering) talán első megnyilvánulása a kreatív ipar területén a Semi-living Steak a The Tissue Culture \& Art Project keretében. Oron Catts és Ionat Zurr 2000-ben a Harvard Medical School Tissue Engineering \& Organ Fabrication Laboratoryjában töltött rezidenciaprogramon hozott létre mesterségesen születés előtti (prenatális) vázizomsejtekből juhszöveteket. ${ }^{26}$ A példaként elemzett projekt a Tiger Penis Project Kuang-Yi Ku szerzőségében, aki a biotechnológia segítségével alkotott meg állatszerveket. A munka fel kívánja hívni a figyelmet azokra az állatokra, amelyeket azért vadásznak, mert a tradicionális kínai orvoslás testükből hatóanyagokat nyer. ${ }^{27}$

Banz-Schulze (2017) i. m. 124-129.

Banz-Schulze (2017) i. m. 80.; Chloé Rutzerveld: Edible Growth. The use of additive manufacturing technologies to create an edible ecosystem. é. n.

24 A projekt 2015. szeptember és 2020. április között volt aktív. Jimmy Day: Project: Personal Food Computer. Overview. Cambridge, Massachusetts Institute of Technology MediaLab, é. n. Schwab (2016) i. m.

Thomas Howells - Leanne Hayman (szerk.): Experimental Eating. London, Black Dog, 2015. 36-38. Anna Winston: Kuang-Yi Ku proposes creating hybrid animal organs for use in Chinese medicine. Dezeen, 2018.

Európai Tükör 2020/4. 


\subsection{Közvetitö online platformok}

Szúrópróbaszerű internetes kereséssel is találhatunk olyan ételeket vagy étkezési lehetőségeket közvetítő online felületeket, amelyek séfeket közvetítenek, amelyek konyhát adnak bérbe, amelyek emberi erővel vagy drónok által ételt vagy hozzávalókat szállítanak házhoz, amelyek étkezési eseményeket vagy étteremfoglalásokat kínálnak. A házhozszállítást intéző gyűjtőoldalak jelentősége különösen megemelkedett a Covid19-vírus okozta világjárvány következtében. A FoodTech kifejezés élelmiszeripari vállalkozásokat és startupokat takar, amelyek a termeléstől a disztribúcióig kínálnak innovatív megoldásokat. ${ }^{28}$ Közülük érdemes kiemelni az ételpazarlás csökkentését megcélzó, az ételmaradék elosztását megszervező Olio és FoodRescue, továbbá a magyar Munch és FoodFinder oldalakat.

\subsection{Digitális kommenzalitás}

Charles Spence, Maurizio Mancini és Gijs Huisman arra a következtetésre jutottak, hogy a társas étkezés, amely nem közös fizikai térben és asztalnál, hanem képernyő általi összeköttetésben megy végbe, azt a pszichológiai szükségletet szolgálja, amely az elmagányosodott étkezésbe kapcsol ismerős vagy ismeretlen partnert. A skeating - azaz a skyping while eating szavak összevonásából származó - kifejezéssel illették azt a tevékenységet, amely során Skype vagy más videóhívás-szolgáltató segítségével virtuális térben tudnak együtt étkezni a felhasználók. Léteznek aszinkron megoldások, amelyek képesek kezelni az időzónák közötti időeltolódást (például a Kizuna), és valós idejűek, amelyek az egy térben levés illúzióját hivatottak kelteni (például a roomXT). ${ }^{29}$

\subsection{Kiterjesztett és virtuális valóság}

Bizonyos értelemben digitális kommenzalitásnak is tekinthető a You Better Eat to Survive! címú számítógépes játék, amelyben az AR-szemüveget hordó gamert az AR-szemüveget nem hordó játékostársa segíti azzal, hogy a megfelelő állomásokon különböző falatokat ad a szájába. Az étel és az étkezés a rágás hangja által kapcsolódik be, amelyet szenzorokkal érzékelnek és közvetítenek. ${ }^{30}$

A Second Livestock nevű terv ígéretében baromfik életminőségének javítása érhető el a haszonállatok számára speciális VR-szemüvegek biztosításával. A koncepció magában foglalja a Chicken Computer Interface névre keresztelt jelenség demonstrációját, amely az Ipar 4.0 egyik hívószavaként ismert Human-Machine Interaction szatirikus analógiájaként értelmezhető. ${ }^{31}$

\footnotetext{
$28 \quad$ DigitalFoodLab (é. n.) i. m.

29 Charles Spence - Maurizio Mancini - Gijs Huisman: Digital Commensality: Eating and Drinking in the Company of Technology. Frontiers in Psychology, 10. (2019), 3. 9-11.

30 Dolejšová et alii (2018) i. m. 3., 7.

31 Banz-Schulze (2017) i. m. 26-29.
} 
Egyes éttermek (például a londoni Inamo Restaurant vagy a budapesti Uncensored Restaurant) a vendégélmény fokozása érdekében minden érzékszervet kiszolgálnak, amikor virtuális realitást, adott esetben tájképeket projektálnak az enteriőrbe vagy interaktív kezelőfelületekre. ${ }^{32}$

\section{Eredmények}

A fentiekben ismertetett food design klasszifikációkat, megközelítéseket és projekteket az alábbi két táblázat foglalja rendszerbe, és kapcsolja össze az Ipar 4.0 hívószavaival.

\section{5. táblázat}

Digitális food design projektek klasszifikációja

\begin{tabular}{|c|c|c|c|c|c|c|c|c|c|c|}
\hline \multirow[b]{2}{*}{ Projektnevek } & \multicolumn{6}{|c|}{ Zampollo-féle szubdiszciplínák } & \multicolumn{4}{|c|}{ V \& A kiállítási szekciók } \\
\hline & 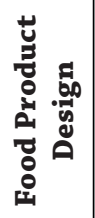 & 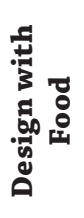 & 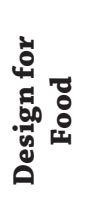 & 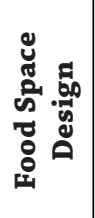 & 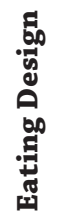 & 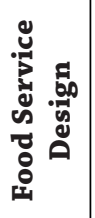 & $\begin{array}{l}\text { ". } \\
\text { : } \\
\text { : }\end{array}$ & 量 & 幽 & تָ \\
\hline Copy Pastry & & & $\mathrm{x}$ & & & & & & & $\mathrm{x}$ \\
\hline $\begin{array}{l}\text { Martí Guixé: } \\
\text { Digital Food }\end{array}$ & $\mathrm{x}$ & & & & & & & & & $\mathrm{x}$ \\
\hline Edible Growth & $\mathrm{x}$ & & & $\mathrm{x}$ & & & & $\mathrm{x}$ & & $\mathrm{x}$ \\
\hline $\begin{array}{c}\text { OpenAg } \\
\text { Personal Food } \\
\text { Computer }\end{array}$ & & & & $\mathrm{x}$ & & & & $\mathrm{x}$ & & \\
\hline $\begin{array}{c}\text { The Tiger Penis } \\
\text { Project }\end{array}$ & & $\mathrm{x}$ & & & & & & & & $\mathrm{x}$ \\
\hline $\begin{array}{l}\text { olioex.com \& } \\
\text { foodrescue.us } \\
\text { \& munch.hu } \\
\text { \&foodfinder.hu }\end{array}$ & & & & & & $\mathrm{x}$ & $\mathrm{x}$ & & $\mathrm{x}$ & \\
\hline $\begin{array}{c}\text { KIZUNA \& } \\
\text { roomXT }\end{array}$ & & & & & $\mathrm{x}$ & & & & & $\mathrm{x}$ \\
\hline $\begin{array}{c}\text { You Better Eat to } \\
\text { Survive! }\end{array}$ & & & & & $\mathrm{x}$ & & & & & $\mathrm{x}$ \\
\hline $\begin{array}{l}\text { Uncensored } \\
\text { Restaurant }\end{array}$ & & & & $\mathrm{x}$ & & & & & & $\mathrm{x}$ \\
\hline Second Livestock & & & & $\mathrm{x}$ & & & & $\mathrm{x}$ & & \\
\hline
\end{tabular}

Forrás: a szerző szerkesztése 
6. táblázat

Digitális food design projektek hívószavak és attitüdök szerint

\begin{tabular}{|c|c|c|c|c|}
\hline \multirow{2}{*}{ Projektnevek } & \multirow{2}{*}{ Hívószavak } & \multicolumn{3}{|c|}{ Attitüdök } \\
\cline { 3 - 5 } & & Élmény- & Kritikaikíció & $\begin{array}{c}\text { Fenntart- } \\
\text { jelleg } \\
\text { hatóság }\end{array}$ \\
\hline Copy Pastry & 3D print & $\mathrm{x}$ & & \\
\hline Martí Guixé: Digital Food & 3D print, data analysis & & $\mathrm{x}$ & $\mathrm{x}$ \\
\hline Edible Growth & 3D print & $\mathrm{x}$ & & $\mathrm{x}$ \\
\hline $\begin{array}{c}\text { OpenAg Tr Personal Food } \\
\text { Computer }\end{array}$ & data analysis, HMI & & & $\mathrm{x}$ \\
\hline The Tiger Penis Project & tissue engineering & & & $\mathrm{x}$ \\
\hline $\begin{array}{c}\text { olioex.com \& foodrescue.us } \\
\text { \& munch.hu \&foodfinder.hu }\end{array}$ & FoodTech, IoS & & $\mathrm{x}$ & $\mathrm{x}$ \\
\hline KIZUNA \& roomXT & VR, ICT & $\mathrm{x}$ & & \\
\hline You Better Eat to Survive! & AR, HFI & $\mathrm{x}$ & & \\
\hline Uncensored Restaurant & VR, HFI & $\mathrm{x}$ & & \\
\hline Second Livestock & AR & & $\mathrm{x}$ & \\
\hline
\end{tabular}

Forrás: a szerző szerkesztése

$\mathrm{Az}$ 5. táblázat példázza, hogy nem minden food design projekt sorolható be egyértelműen egy-egy osztályba vagy szekcióba. Egyetlen példát említve, az Edible Growth címú munka egyszerre tekinthető a zampollói osztályozás szerint Food Product Designnak, hiszen ipari termelésre szánják, és ez irányú fejlesztéséért dolgoznak, valamint Food Space Designnak, hiszen bizonyos értelemben az étel elkészítésére szolgáló hely megalkotásáról van szó a tésztastruktúra belsejében lévő, gombákat és növényeket növesztő massza esetében. Ez a pont rámutat a zampollói klasszifikáció kritikai felülvizsgálatának lehetőségére az Ipar 4.0 technológiai innovációinak fényében (vö. 6. táblázat).

\section{6. Összefoglalás}

A fenti áttekintés hiánypótló vállalkozás arra vonatkozóan, hogy az Ipar 4.0 jellemzőit a food design rendszerében láttassa. Ehhez szükséges az Ipar 4.0 fogalmát és legfontosabb alkalmazásait, majd a food design csoportosítási lehetőségeit, valamint szociális és ökonómiai katalizátor jellegét adó megközelítéseit ismertetni. A munka irodalmi áttekintésen és egyéni gyưjtésen alapuló, végső soron szubjektív szelekciót nyújt olyan food design projektek bemutatásáról, amelyek kapcsolatba hozhatók a digitalizációval. A létrejött bonyolult összefüggésrendszer felvázolására a táblázatos forma kínált optimális megoldást, amely alapján lehetőség kínálkozik a Zampollo-féle food design klasszifikáció újragondolására. 


\section{Felhasznált irodalom}

Banz, Claudia - Sabine Schulze (szerk.): Food Revolution 5.0. Gestaltung für die Gesellschaft von morgen. Hamburg, Verlag Kettler, 2017.

Brettel, Malte - Niklas Friederichsen - Michael Keller - Marius Rosenberg: How virtualization, decentralization and network building change the manufacturing landscape: An Industry 4.0 Perspective. International Journal of Mechanical, Industrial Science and Engineering, 8. (2014), 1. 37-44. Online: https://doi.org/10.5281/zenodo.1336426

Day, Jimmy: Project: Personal Food Computer. Overview. Cambridge, Massachusetts Institute of Technology MediaLab, (é. n.) Online: www.media.mit.edu/projects/personal-food-computer/overview/

Demartini, Melissa - Claudia Pinna - Flavio Tonelli - Sergio Terzi - Cinzia Sansone - Chiara Testa: Food industry digitalization: from challenges and trends to opportunities and solutions. IFAC PapersOnLine, 51. (2018), 11. 1371-1378. Online: https://doi. org/10.1016/j.ifacol.2018.08.337

DigitalFoodLab: What is FoodTech? é. n. Online: www.digitalfoodlab.com/foodtech

Dolejšová, Markéta - Rohit Ashok Khot - Hilary Davis - Hasan Shahid Ferdous - Andrew Quitmeyer: Designing Recipes for Digital Food Futures. In CHI EA, 18: Extended Abstracts of the 2018 CHI Conference on Human Factors in Computing Systems. New York, Association for Computing Machinery, 2018. 1-8. Online: https://doi. org/10.1145/3170427.3170622

Dunne, Anthony - Fiona Raby: Towards a Critical Design. é. n. Online: http://dunneandraby.co.uk/content/bydandr/42/0

Faludi Julianna: Cukorépítészet, avagy főzés-e az ételnyomtatás? Café Bábel, 80. (2019). 152-160.

Flood, Catherine - May R. Sloan: FOOD: Bigger than the Plate. London, Victoria and Albert Museum, 2019.

Geissbauer, Reinhard - Jesper Vedso - Stefan Schrauf: Industry 4.0: Building the digital enterprise. Pricewaterhouse-Coopers LLP, 2016.

Güneş, Eda - Şerife Biçer Bayram - Melike Özkan - H. Ferhan Nizamlığlu: Gastronomy Four Zero (4.0). International Journal of Environmental Pollution \& Environmental Modelling, 1. (2018), 3. 77-84.

Hablesreiter, Martin: Food Design [dokumentumfilm], 2008.

Hofmann, Erik - Marco Rüsch: Industry 4.0 and the current status as well as future prospects on logistics. Computers in Industry, 89. (2017). 23-34. Online: http://dx. doi.org/10.1016/j.compind.2017.04.002

Howells, Thomas - Leanne Hayman (szerk.): Experimental Eating. London, Black Dog, 2015.

Kovács Olivér: Az ipar 4.0 komplexitása. Közgazdasági Szemle, 64. (2017), 7-8. 823-851. Online: http://dx.doi.org/10.18414/KSZ.2017.7-8.823

Molich-Hou, Michael: Food 3D Printing: What Happened to 3D-Printed Food for the Elderly? 3D Print, 2020. Online: 3dprint.com/267312/food-3d-printing-what-happenedto-3d-printed-food-for-the-elderly/?utm_source=dlvr.it\&utm_medium=linkedin

Európai Tükör 2020/4. 
Nagy Judit: Az Ipar 4.0 fogalma és kritikus kérdései - vállalati interjúk alapján. Vezetéstudomány - Budapest Management Review, 50. (2019), 1. 14-26. Online: https://doi. org/10.14267/VEZTUD.2019.01.02

Pine, B. Joseph - James H. Gilmore: The Experience Economy: Work is Theatre \& Every Business a Stage. Boston, Harvard Business Press, 1999.

Prause, Gunnar: Sustainable business models and structures for Industry 4.0. Journal of Security and Sustainability Issues, 5. (2015), 2. 159-169. Online: https://doi. org/10.9770/jssi.2015.5.2(3)

Rutzerveld, Chloé: Edible Growth. The use of additive manufacturing technologies to create an edible ecosystem. é. n. Online: www.chloerutzerveld.com/edible-growth

Schulze, Gerhard: Die Erlebnisgesellschaft: Kultursoziologie der Gegenwart. Frankfurt am Main, Campus, 1992.

Schwab, Klaus: The Fourth Industrial Revolution: what it means, how to respond. World Economic Forum, 2016. Online: www.weforum.org/agenda/2016/01/the-fourthindustrial-revolution-what-it-means-and-how-to-respond/

Spence, Charles - Maurizio Mancini - Gijs Huisman: Digital Commensality: Eating and Drinking in the Company of Technology. Frontiers in Psychology, 10. (2019). 1-16. Online: https://doi.org/10.3389/fpsyg.2019.02252

Winston, Anna: Kuang-Yi Ku proposes creating hybrid animal organs for use in Chinese medicine. Dezeen, 2018. Online: www.dezeen.com/2018/10/15/tiger-penis-project-chinese-medicine-synthetic-biology-kuang-yi-ku-design/

Zampollo, Francesca: Let's Food Design: 7 Steps to Become a Food Designer. CreateSpace Independent Publishing Platform, 2016. 